\title{
Human-directed social behaviour in dogs shows significant heritability
}

\author{
Mia Persson, Lina Roth, Martin Johnsson, Dominic Wright and Per Jensen
}

\section{Linköping University Post Print}

\section{Tweet}

N.B.: When citing this work, cite the original article.

Original Publication:

Mia Persson, Lina Roth, Martin Johnsson, Dominic Wright and Per Jensen, Human-directed social behaviour in dogs shows significant heritability, 2015, Genes, Brain and Behavior, (14), 4, 337-344.

http://dx.doi.org/10.1111/gbb.12194

Copyright: Wiley: 12 months

http://eu.wiley.com/WileyCDA/

Postprint available at: Linköping University Electronic Press

http://urn.kb.se/resolve?urn=urn:nbn:se:liu:diva-117523 


\section{Human-directed social behaviour in dogs shows significant heritability}

Running title: Heritability of social behaviour in dogs

Mia E. Persson, Lina S. V. Roth, Martin Johnsson, Dominic Wright, Per Jensen*

IFM Biology, AVIAN Behaviour Genomics and Physiology Group, Linköping University, 58183 Linköping, Sweden

* Corresponding author: perje@ifm.liu.se, phone number: +46 13 281298, fax number:

+4613281399

Date of submission: 2014-04-30

Key words: dogs, domestic dog, beagles, heritability, social behaviour, canine behaviour, problem-solving, genetics, human-directed communication, eye contact

Abstract: 245 words

Introduction: 493 words

Discussion: 1463 words 


\section{Abstract}

Through domestication and co-evolution with humans, dogs have developed abilities to attract human attention, e.g. in a manner of seeking assistance when faced with a problem solving task. The aims of this study were to investigate within breed variation in human-directed contact seeking in dogs and to estimate its genetic basis. To do this, 498 research beagles, bred and kept under standardised conditions, were tested in an unsolvable problem task. Contact seeking behaviours recorded included both eye contact and physical interactions. Behavioural data was summarised through a principal component analysis, resulting in four components: test interactions, social interactions, eye contact and physical contact. Females scored significantly higher on social interactions and physical contact and age had an effect on eye contact scores. Narrow sense heritabilities $\left(\mathrm{h}^{2}\right)$ of the two largest components were estimated at 0.32 and 0.23 but were not significant for the last two components. These results show that within the studied dog population, behavioural variation in human-directed social behaviours was sex dependent and that the utilisation of eye contact seeking increased with age and experience. Hence, heritability estimates indicate a significant genetic contribution to the variation found in human-directed social interactions, suggesting that social skills in dogs have a genetic basis, but can also be shaped and enhanced through individual experiences. This research gives the opportunity to further investigate the genetics behind dogs' social skills, which could also play a significant part into research on human social disorders such as autism.

\section{Introduction}

The dog was the first domesticated animal (Freedman et al., 2014, Vila et al., 1997), and through co-evolution with humans, it has been reported to have developed certain 
human-like social skills (Hare \& Tomasello, 2005, Topal et al., 2009), such as sensitivity to human ostensive cues and comprehension of referential gestures (Lakatos et al., 2012, Soproni et al., 2001, Téglás et al., 2012). Hence, dogs have become important models in comparative cognition studies (Hare et al., 2002, Hare \& Tomasello, 2005, Miklosi et al., 2004, Topal et al., 2009). However, since dogs are normally raised close to human companions, social experience is also important in forming their social skills, apart from the possible genetic adaptations acquired during domestication. Therefore, it is desirable to study dogs raised under standardised conditions with respect to human contact and interactions, to reduce this environmental variation. The aim of the present experiment was to do exactly this, utilising a unique population of laboratory beagles.

Dogs may display intentional referential communicative acts towards humans involving both a directional and attention-seeking component (Marshall-Pescini et al., 2013, Miklosi et al., 2000). These human-directed social skills are usually not found to the same extent in wolves (Gacsi et al., 2009, Miklosi et al., 2003, Viranyi et al., 2008), indicating a genetic component to the communicative skills, which may have been selected during domestication. This is further supported by the observation that foxes selected for tameness perform as well as dogs and significantly better than control foxes in similar tasks (Hare et al., 2005). Additionally, breed differences have been reported in the ability to follow human communicative cues (Passalacqua et al., 2011, Udell et al., 2014, Wobber et al., 2009). All these results suggest that social skills in dogs are the direct result of domestication, probably have a genetic basis and have been selected for and further enhanced in some breeds. A wider genetic characterisation of this is still lacking.

Narrow-sense heritability $\left(\mathrm{h}^{2}\right)$ estimates the additive genetic contribution to a phenotypic trait, such as dogs' social skills (Visscher et al., 2008, Wilson et al., 2011) and 
this has e.g. been investigated in hunting behaviour (Lindberg et al., 2004), working performance (Ruefenacht et al., 2002), aggression (Liinamo et al., 2007, Perez-Guisado et al., 2006) and some social skills like greeting behaviour (Saetre et al., 2006) and affability (Van Der Waaij et al., 2008). To our knowledge, no studies have yet investigated the heritability of human-directed social behaviour in dogs raised under standardised conditions.

In this project, we performed a behavioural test, targeting the communicative skills of dogs, on a large, well defined population of laboratory beagles, bred and housed under highly standardised conditions. The test utilised the so-called "unsolvable problem" paradigm (Topal et al., 1997). In this, dogs are allowed to explore an unsolvable foodsearch problem and the propensity of the dog to seek human contact and cooperation is measured. The aims were to evaluate within-breed variation and heritability in humandirected contact seeking behaviour.

\section{Materials and methods}

\section{Ethical note}

This research was approved by the Swedish ethics committee in Lund, Sweden (201206-21).

\section{Housing and handling}

Beagles, bred and kept under standardised conditions, at a research dog kennel were used in this study. In total there were approximately 10 caretakers, both male and female, rotating their tasks and care for the dogs and facilities. One member of the staff would therefore not necessarily always work in the same stables. Whelping and nursing 
was carried out in a separate nursery unit, where the dogs were kept until eight weeks of age. After weaning, they were housed in groups of 2-4 same sexed (usually not from the same litter) individuals in pens, composed of both an indoor (2-3 X 3-4 m) and an outdoor area (3-4 X $6 \mathrm{~m}$ ) with gravel and sand mixed flooring, elevated platforms and chewing toys which they had constant access to.

The dogs were fed in the morning, once a day at the same time and usually in the outside pens and they had a constant ad libitum supply of water. Puppies were handled and socialised according to a predetermined schedule, specifying activities on a weekly basis from 4 until 13 weeks of age. Until the dogs were 11 months of age they were weighed, had their claws cut and were trained to walk on a leash on a monthly basis.

The staff at the kennel performed a simple sociability test at 5 and 11 months of age, and at 49 weeks a final test was carried out, in order to judge the suitability of the dogs for participation in different medical research projects. In addition, handling of dogs was scheduled for nail-cutting, and they were moved to a larger outdoor play pen for a couple of hours every second week or when being rearranged to other pens. When being moved to play pens the keepers let them walk on a leash. Dogs were handled outside of the schedule whenever they needed veterinary attention. Apart from this, dogs were not handled.

\section{Animals tested}

All tests, as well as handling prior to and during testing, was carried out by the same female experimenter (first author) and were standardised and performed according to what is described here. In total, 498 beagles were all tested once each. We first carried out an initial feeding test, investigating whether dogs were qualified to perform the actual behaviour test (see below for details of this). Out of the 498 dogs, 437 qualified 
for the behaviour test (196 males and 241 females, median age 1.3 years). The majority of dogs tested were young (388 individuals ranging from 8 months to 2.4 years of age), but breeding animals were also tested (49 individuals ranging from 2 to 6 years of age).

Most of the beagles had at least one parent for which the pedigree could be traced back on the kennel for 6-10 generations. However, 14 individuals had been imported from other research kennels and were not related to the rest of the dogs. These individuals were excluded from genetic analysis.

\section{Procedure}

The same female experimenter handled the dogs during the testing (from the point of collecting them in their home pens until they were put back again), and also carried out the behaviour tests. The experimenter captured dogs in a random order, one at a time in their home pens, and when placed back, the next dog was taken from another pen. A martingale collar with a leash was used when walking the dogs from their home pen to the procedure room. Dogs that would not walk on the leash were instead picked up and carried to the procedure room. While the dogs were on the leash just outside their home pen, approximately five attempts were performed to achieve eye contact. The experimenter did this by first kneeling down (hunching down with one or two knees on the ground) and talking to the dog in a calm and encouraging manner (talking in normal to low volume with slightly higher pitch than normal, with the intention of being positive and inviting). If the dog would not look at or seek eye contact with the experimenter within approximately 20 seconds, the leash was slowly shortened until the experimenter could softly pat the dog and make eye contact. After this, it was usually enough to talk encouraging to the dog for it to again seek eye contact. Otherwise, the previous procedure was repeated once more, so a maximum of 
two times, which was enough for all dogs to seek eye contact with the experimenter. If the dog did not immediately seek eye contact when the experimenter was kneeling down, the procedure took about one minute. Otherwise, the duration of this eye contact establishing procedure was slightly shorter. As it was repeated 5 times, it took about 5 minutes in total for each dog. The collar was removed upon entering the test room and the dog was allowed to move around freely for approximately 2 minutes. The test room was approximately $3.5 \mathrm{X} 4$ meters, empty from furniture, and windows were covered.

The ID of the dog was checked and noted by reading the ear tattoo. This was then written on a small whiteboard presented in front of the video camera (Canon Legria HF M52) as the video recording was started for each dog (see below). Continuous recording took place from this point forward, until the dog either failed the initial feeding test or until the end of the entire test.

\section{The initial feeding test and the Feeding Score}

In order to test how willing the dogs were to eat the treats, they were presented with a treat (quarter pieces of normal sized FROLIC®) on a single plate, similar to those used in the test setup later but without a cover (Figure 1). After placing the single plate containing a treat on the floor, the test leader was standing passively in the same position. If the dog ate a treat, another was placed on the plate, without picking it up, until the dog had eaten a total of three treats. The initial feeding test had a maximum duration of 2 minutes. However, some individuals would continue to explore the procedure room by sniffing the floor and walls instead of having their visual attention directed towards the plate. Therefore, if the dog did not show interest in (visual and 
physical orientation towards the object) the plate within approximately 30 seconds, the experimenter tried to redirect its attention towards the treat by placing it directly on the floor within $20 \mathrm{~cm}$ of the plate. If the dog was not visually orientated towards the treat while it was placed on the floor, the test leader would talk to the dog and indicate the location of the treat by pointing at it with her right hand until she was sure the dog had seen the treat, and then she went back to standing passively. Most dogs would eat the treat when placed on the floor. The next treat was again initially placed on the plate, but moved to the floor next to the plate if the dog did not eat it within 30 seconds. If the dog had not eaten all treats after approximately two minutes from when the plate was first put down, the dog did not qualify for the unsolvable task. On the other hand, if the dog ate all the treats it had qualified, and the plate was replaced with the unsolvable task. During testing, a stopwatch was used to keep track of the time recording, however, later these video sections were analysed using The Observer XT 10 software. Feeding was scored based upon the latency until eating the first treat (Feeding Score) for each individual on a scale from 1-3 where 1 was late feeding, 2 was medium feeding and 3 was early feeding (Table 1).

\section{The unsolvable task}

The device for the unsolvable task consisted of three plates (Figure 1) on a solid foundation, each covered with transparent Plexiglas lids with six $0.5 \mathrm{~mm}$ odour ports. The test setup was placed on the floor approximately 15-20 centimeters from the wall. Two of the three plastic covers could be easily pushed to the side giving access to the treat underneath, while the third lid (the middle one) could not be opened. The experimenter sat on a stool approximately 1.5 meters from the test setup facing towards it. During three minutes, the dog was allowed to freely move around the 
room and manipulate the unsolvable task. If the dog had not succeeded to reach any of the treats after 60 seconds, the experimenter opened both plastic covers halfway and sat down again. The total duration of the test was 3 minutes. After each test, the floor and the entire test equipment was cleaned and prepared for the next dog.

\section{Data analysis, ethogram and scoring}

Videos were analysed and behaviours were scored using The Observer XT 10 software. For every subject, ID, sex, date of birth, date and time of testing were noted. The ethogram used for the recordings is shown in Table 2. For each behaviour, frequency, latency and duration were recorded and the latencies for the dog to solve the first and the second solvable tasks were noted. Additionally, a "Transition Index" was calculated by summing up the total number of direct transitions, which the dog made between the experimenter and the test setup. Direct transitions were those where the dogs' head did not leave the zone, within its own body length, of the test setup before entering the zone of the experimenter, and vice versa. From each video recording, the dogs' Feeding Score (Table 1), as previously mentioned, and Body Posture Score (Table 3) were scored on a scale from 1 to 5 where 1 is low body and tail posture and 5 is high body and tail posture.

\section{Pedigree}

Dogs tested were all from an outbred population of research beagles. Astra Zeneca provided the pedigree used for breeding purposes. By tracing the ancestry of the 437 tested dogs, we ended up with a total of 643 individuals in the pedigree used for heritability calculations. For one of the tested dogs, ancestry was unknown, so it was excluded from further analysis. The tested individuals belonged to 160 different litters. 


\section{Statistical analysis of behaviour}

All statistical analyses, except for heritability calculations, were performed in IBM SPSS Statistics 22.

First, a Principal Component Analysis was carried out on all the behavioural variables. Sampling adequacy: Bartlett's sphericity test $\chi^{2}=7899.66, \mathrm{df}=210, \mathrm{p}<$ 0.001; KMO: 0.855 . Eigenvalue $>1$ was the criterion used to determine the four principal components used for further analysis and no factor rotation was used. (The original correlation matrix can be found in the supplementary material, Table S1)

Data was checked for normality, both visually and with the Kolmogorov-Smirnov test, and, if necessary, transformed $(\log 10(x+1))$. Then, effects of sex and age as well as their interaction were investigated using Univariate General Linear Models in SPSS Statistics 22. Effects of age, sex and their interactions were investigated for each behavioural variable and for the scores on each of the four Principal Components. In the model, sex was set as a fixed factor and age as a covariate. If the interaction was not significant, it was removed from the model and only the main effects of sex and age were used in the analysis. Age ranged from 0.7 to 6.2 years with an average age of 1.5 years and a median age of 1.3 years.

\section{Calculations of heritability}

Narrow sense heritability $\left(h^{2}\right)$ was estimated for the scores on each of the four principal components, using linear mixed animal models (Kruuk, 2004). Animal models can be fitted with either classical restricted maximum likelihood methods or 
by Bayesian inference. We used Bayesian methods and Markov Chain Monte Carlo simulations as implemented in the MCMCglmm package for R (Hadfield, 2010). This approach has been used previously to estimate genetic parameters in pedigrees of wild and domestic animals, for instance by Serbezov et al. (2010) and Oberbauer et al. (2013). Models included sex and age as fixed effects and an additive genetic effect with a variance-covariance matrix equal to the estimated variance times the additive relationship matrix. Errors were assumed to be independent with equal variance. Hence, we fit two variance components, the additive genetic and residual, and calculated heritability as the additive genetic variance divided by the sum of the variance components. For each principal component, we report the posterior mean of the heritability as well as the $95 \%$ highest posterior density interval based on MCMC draws from the posterior distribution. We used a parameter expanded prior for the genetic variance component with $\mathrm{V}=1, v=1, \alpha_{\mu}=0, \alpha_{\mathrm{V}}=1000$, which is a halfCauchy prior for the standard deviation with scale 100 (Gelman, 2006), and inverseWishart priors $(\mathrm{V}=1, v=0.002)$ for the residual variance component. The halfCauchy prior is less informative than the inverse-Wishart when the variance component is small. The fixed effects had diffuse normal priors. Chains were run for 5 million iterations with a burn-in of 3000 samples and a thinning interval of 100 samples. Convergence was tested with Heidelberg and Welsh's diagnostic, and autocorrelation measured between every $100^{\text {th }}$ thinned samples was below 0.1 .

\section{Results}

The results for each of the behavioural variables are given in the supplementary material (Table S2). The original behaviour variables, recorded and scored as described in the methods section, were combined into four Principal Components 
with Eigenvalues $>1$ by means of the Principal Component Analysis described above. These four Principal Components together explained $71.7 \%$ of the total variance in the original behaviour variables (Table 3). The Principal Components were tentatively named, based on how the original behaviour variables loaded on each of them. The first component was named Test interactions, since it was mainly comprised of variables related to frequency and durations of time spent interacting with the test setup as well as Feeding Score and Transition Index. It was also negatively related to the latency to approach the test setup and to solve the problems, as well as to the Body Posture Score and duration spent by the human. The second component was named Social interactions, and had high loadings of Transition Index, frequency and duration spent by, and interacting with, the human as well as negative loadings for the latency to approach the human and for contact seeking behaviours. The third component was called Eye contact and mainly relates to the frequency and duration of eye contact seeking behaviour as well as a shorter latency to seek eye contact. The fourth component, named Physical contact, relates to the duration dogs spent in physical contact with the human and was negatively related to the frequency of visits to the test setup. Hence, the behaviour of each of the dogs could be represented by their scores on each of the four calculated Principal Components, rather than by their original behaviour recordings.

There was no significant effect of sex or age separately on principal component scores (PC scores) on Test interactions, however, there was a significant interaction between sex and age (Fig 2a; $\left.F_{1,432}=11.23 ; \mathrm{p}<0.01\right)$. On the other hand, PC scores on Social interaction was significantly affected by $\operatorname{sex}\left(\right.$ Fig $\left.3 ; F_{1,432}=17.60 ; p<0.01\right)$ where females had higher scores. Sex did not affect PC scores on Eye contact but age had a significant effect on this component (Fig $2 \mathrm{~b} ; \mathrm{F}_{1,432}=8.39 ; \mathrm{p}<0.01$ ). Note that the PC 
scores are reversed in this case, so a higher score means less eye contact. PC scores on Physical contact differed significantly between males and females (Fig 3; $\mathrm{F}_{1,432}=6.53 ; \mathrm{p}$ $=0.01$ ) but was not affected by age (results are shown in supplementary Table S2). Also noteworthy is the difference between males $(3.0 \pm 0.16)$ and females $(3.7 \pm 0.18)$ in Transition Index $\left(\mathrm{F}_{1,432}=7.94 ; \mathrm{p}<0.01\right)$.

Heritability estimates of the principal components are presented in Table 5. For PC scores on Test interactions (PC1), heritability was estimated to 0.32 and for Social interactions (PC2), 0.23. However, the final two components did not have significant heritability estimates. The significance was attributed to the fact that, for the first two components, the lower ends of the HPD intervals were above 0 .

\section{Discussion}

Our results show that behaviours of the beagles in this study, during an unsolvable problem solving task, could be largely accounted for by four Principal Components: Test set interactions, Social interactions, Eye contact and Physical contact. Females were more social than males and sought more physical contact, while age affected eye contact seeking behaviour, where older dogs sought eye contact with the test leader earlier, more frequently, and for a longer duration than younger dogs. Heritability estimates of the Principal Components scores revealed a significant genetic contribution to the behaviours involved in test interactions as well as social interactions.

We used an unsolvable problem task in order to investigate within breed variation of attention seeking behaviour in dogs, as has previously been done in several studies analysing help-seeking behaviour in wolves (Miklosi et al., 2003), dogs (Topal et al., 1997), dingoes (Smith \& Litchfield, 2013), chimpanzees (Leavens et al., 2005) and 
human toddlers (Marshall-Pescini et al., 2013). Most of these studies allow the subjects several trials to learn how to solve the problem task, before presenting them with a blocked trial. Typically dogs, more so than wolves and other non-human species, gaze at humans and seek help in these situations (Topal et al, 1997; Miklosi et al., 2003). However, dogs have been observed to gaze back at humans also in several other situations, such as in an object choice paradigm (Viranyi et al., 2008), detour task (Pongracz et al., 2005), when a desired object is placed out of reach (Gaunet \& Deputte, 2011, Miklosi et al., 2000) and when facing a potentially anxiogenic object (Merola et al., 2012). Here, we designed an unsolvable task whereby dogs could learn how to first solve the task by trial and error, and at the same time were faced with an unsolvable version of the same task. By using this design, each individual was only handled and tested once.

This study is unique in that sense that we tested $\sim 500$ dogs of the same breed, with all individuals bred, maintained and handled in a highly standardised manner. Hence, variation in experience with human interactions was low among the test subjects. This is important to take in consideration when interpreting the results, as the rearing conditions are different from household dogs living in very different social environments. Additionally, this population has been maintained as a single breeding colony for several generations and therefore the phenotypic and genetic variation might not be representative of a population of pet beagles.

Apart from frequencies, latencies and durations of different types of test set and experimenter interaction, feeding and body posture was also scored. The Feeding Score reflects how quickly dogs ate the pre-test treats and a reasonable interpretation of this score is as a measure of food motivation. In the Body Posture Score the overall posture of dogs during testing was given a subjective score that can be interpreted as a measure 
of fearfulness (Schenkel, 1967). When summarising the recorded behaviours through a PCA, behaviours directed towards the test setup separated from human-directed social behaviours, indicating separate behavioural control systems. Age and sex had an interactive effect on test set interactions, where older females had higher principal component scores than older males. Also, females had higher principal component scores than males on human-directed social behaviours and were seeking more physical contact from the experimenter. It is not clear whether all physical interactions were intended as attempts to seek human attention to the unsolvable task, however, females also had a higher Transition Index meaning that they had a higher number of transitions directly between the test apparatus and the test leader. This could be considered as females seeking human attention by physical contact more frequently than males.

The third component of the PCA was negatively correlated with eye contact seeking behaviour and varied with age. Older dogs were better at utilising this behaviour, which may either be a pure age effect, or caused by increased experience of interacting with humans. Similar results were found in a study by Passalacqua et al. (2011) who saw an increase in gazing behaviour with age in young dogs. Additionally, they also observed differences between breed groups where human-directed gazing occurred more in hunting and herding dogs, suggesting that this behaviour is shaped by both genetic factors and life experiences. Jakovcevic et al. (2012) found that more sociable dogs gaze more at human faces than less sociable individuals, and Barrera et al. (2011) suggest that gazing behaviour is highly responsive to associative learning and is used more by pet dogs than shelter dogs, again suggesting an important environmental influence on the behaviour.

Heritability of behaviours related to social interactions towards the human (second Principal Component) was estimated as 0.23 . To our knowledge, there are only a few 
other studies that have estimated a genetic component affecting human-directed contact seeking in dogs. Saetre et al. (2006) estimated the heritability of greeting behaviour in the Swedish Dog Mentality Assessment test to 0.05 in German Shepherds and 0.09 in Labrador retrievers. Additionally, Van Der Waaij et al. (2008) calculated the heritability of a trait they called affability in German Shepherds and Rottweiler dogs. Affability was a score of willingness of dogs to make contact with people. However, the authors state that this was a difficult behavioural variable since it combined both social openness and tendencies to be aggressive or fearful, and a change in the score could therefore represent a change of trait rather than a decrease or increase. The heritability of affability was estimated to 0.38 in German Shepherds and 0.03 in Rottweiler dogs.

Domestication research on other social skills in dogs, such as following of referential gestures, indicates a genetic basis to these traits. One example is the behavioural research performed on Siberian farm foxes selected for tameness (Hare et al., 2005). Foxes selected solely on decreased fear behaviour towards humans also acquired an increased ability to follow human communicative cues. Furthermore, unsocialised puppies outperform wolf pups in following human communicative cues (Hare et al., 2002). Additionally, Udell et al. (2014) found breed group differences in the performance of dogs on a human-guided task, again suggesting a significant genetic basis for social skills in dogs. Considering all of these findings together, the outstanding social skills of dogs are most likely a result of domestication and selective breeding, but can be shaped further by individual experiences.

Although our results provide a strong case for a significant genetic contribution to the variation in social skills of dogs, we cannot say anything about possible genes involved. Very little research has been done in this area in general, but Kis et al. (2014) found that polymorphisms in the oxytocin receptor gene in German Shepherds and Border Collies 
affected their human-directed social behaviour. However, they also found differences in the human-directed social behaviour of the two breeds and two of the polymorphisms had the opposite effect in Border Collies compared to the German shepherd, so the importance of this gene is still unknown. Nevertheless, oxytocin has been shown to increase gaze to the eye region in humans (Graustella \& Macleod, 2012, Guastella et al., 2008) and could be involved in the modulation of eye contact seeking also in dogs. However, Kis et al. (2014) did not find any differences in "looking at humans" between dogs carrying the different alleles of the oxytocin gene.

Genes affecting human-directed social behaviour in dogs could possibly also be found among those related to the brain opioid system (Knowles et al., 1989). In this case, socially deprived dogs were seeking more contact from the experimenter than nondeprived dogs and this was further enhanced if dogs were administered morphine prior to the social-deprivation period. It is, however, important to bear in mind that other genetic influences than polymorphisms could play a role in the behavioural variation seen, such as epigenetic effects (Kappeler \& Meaney, 2010). Maternal epigenetic effects will be partly controlled for by the heritability model used (based as it is on both sire and dam variance combined), though paternal epigenetic and genetic factors will be inseparable from one another.

There is a strong need for further research to find genes and polymorphisms associated with social skills in dogs, and this may also provide important tools for translational research. For example, reduced eye contact and communication have been suggested to be important aspects of human autism spectrum disorders, and dogs may prove to be important models for understanding the genetic basis of this (Donaldson \& Young, 2008, Yamasue et al., 2012). 
In conclusion, we have presented evidence of a significant genetic basis for the abilities of dogs to seek human attention during a problem-solving situation. These results may contribute to the understanding of domestication history of dog social skills and opens up for further analysis of the genetic basis of the human-directed social behaviours.

\section{References}

Barrera, G., Mustaca, A. \& Bentosela, M. (2011) Communication between domestic dogs and humans: effects of shelter housing upon the gaze to the human. Animal cognition, 14, 727-734.

Donaldson, Z.R. \& Young, L.J. (2008) Oxytocin, vasopressin, and the neurogenetics of sociality. Science, 322, 900-904.

Freedman, A.H., Gronau, I., Schweizer, R.M., Ortega-Del Vecchyo, D., Han, E., Silva, P.M., Galaverni, M., Fan, Z., Marx, P., Lorente-Galdos, B., Beale, H., Ramirez, O., Hormozdiari, F., Alkan, C., Vilà, C., Squire, K., Geffen, E., Kusak, J., Boyko, A.R., Parker, H.G., Lee, C., Tadigotla, V., Siepel, A., Bustamante, C.D., Harkins, T.T., Nelson, S.F., Ostrander, E.A., Marques-Bonet, T., Wayne, R.K. \& Novembre, J. (2014) Genome Sequencing Highlights the Dynamic Early History of Dogs. Plos Genet, 10, e1004016.

Gacsi, M., Gyori, B., Viranyi, Z., Kubinyi, E., Range, F., Belenyi, B. \& Miklosi, A. (2009) Explaining Dog Wolf Differences in Utilizing Human Pointing Gestures: Selection for Synergistic Shifts in the Development of Some Social Skills. Plos One, 4.

Gaunet, F. \& Deputte, B.L. (2011) Functionally referential and intentional communication in the domestic dog: effects of spatial and social contexts. Animal cognition, 14, 849-860.

Gelman, A. (2006) Prior distributions for variance parameters in hierarchical models(Comment on an Article by Browne and Draper). Bayesian Anal, 1, 515-533.

Graustella, A.J. \& MacLeod, C. (2012) A critical review of the influence of oxytocin nasal spray on social cognition in humans: Evidence and future directions. Horm Behav, 61, 410-418.

Guastella, A.J., Mitchell, P.B. \& Dadds, M.R. (2008) Oxytocin increases gaze to the eye region of human faces. Biol Psychiat, 63, 3-5.

Hadfield, J.D. (2010) MCMC Methods for Multi-Response Generalized Linear Mixed Models: The MCMCglmm R Package. J Stat Softw, 33, 1-22.

Hare, B., Brown, M., Williamson, C. \& Tomasello, M. (2002) The domestication of social cognition in dogs. Science, 298, 1634-1636.

Hare, B., Plyusnina, I., Ignacio, N., Schepina, O., Stepika, A., Wrangham, R. \& Trut, L. (2005) Social cognitive evolution in captive foxes is a correlated byproduct of experimental domestication. Curr Biol, 15, 226-230.

Hare, B. \& Tomasello, M. (2005) Human-like social skills in dogs? Trends in cognitive sciences, 9, 439-444.

Jakovcevic, A., Mustaca, A. \& Bentosela, M. (2012) Do more sociable dogs gaze longer to the human face than less sociable ones? Behav Process, 90, 217 222. 
Kappeler, L. \& Meaney, M.J. (2010) Epigenetics and parental effects. Bioessays, 32, 818-827.

Kis, A., Bence, M., Lakatos, G., Pergel, E., Turcsan, B., Pluijmakers, J., Vas, J., Elek, Z., Bruder, I., Foldi, L., Sasvari-Szekely, M., Miklosi, A., Ronai, Z. \& Kubinyi, E. (2014) Oxytocin Receptor Gene Polymorphisms Are Associated with Human Directed Social Behavior in Dogs (Canis familiaris). Plos One, 9.

Knowles, P.A., Conner, R.L. \& Panksepp, J. (1989) Opiate Effects on SocialBehavior of Juvenile Dogs as a Function of Social Deprivation. Pharmacol Biochem Be, 33, 533-537.

Kruuk, L.E.B. (2004) Estimating genetic parameters in natural populations using the 'animal model'. Philos T Roy Soc B, 359, 873-890.

Lakatos, G., Gácsi, M., Topál, J. \& Miklósi, Á. (2012) Comprehension and utilisation of pointing gestures and gazing in dog-human communication in relatively complex situations. Animal cognition, 15, 201-213.

Leavens, D.A., Russell, J.L. \& Hopkins, W.D. (2005) Intentionality as measured in the persistence and elaboration of communication by chimpanzees (Pan troglodytes). Child Dev, 76, 291-306.

Liinamo, A.E., van den Berg, L., Leegwater, P.A.J., Schilder, M.B.H., van Arendonk, J.A.M. \& van Oost, B.A. (2007) Genetic variation in aggression-related traits in Golden Retriever dogs. Appl Anim Behav Sci, 104, 95-106.

Lindberg, S., Strandberg, E. \& Swenson, L. (2004) Genetic analysis of hunting behaviour in Swedish Flatcoated Retrievers. Appl Anim Behav Sci, 88, 289298.

Marshall-Pescini, S., Colombo, E., Passalacqua, C., Merola, I. \& Prato-Previde, E. (2013) Gaze alternation in dogs and toddlers in an unsolvable task: evidence of an audience effect. Animal cognition, 16, 933-943.

Merola, I., Prato-Previde, E. \& Marshall-Pescini, S. (2012) Social referencing in dog-owner dyads? Animal cognition, 15, 175-185.

Miklosi, A., Kubinyi, E., Topal, J., Gacsi, M., Viranyi, Z. \& Csanyi, V. (2003) A simple reason for a big difference: wolves do not look back at humans, but dogs do. Curr Biol, 13, 763-766.

Miklosi, A., Polgardi, R., Topal, J. \& Csanyi, V. (2000) Intentional behaviour in doghuman communication: an experimental analysis of "showing" behaviour in the dog. Animal cognition, 3, 159-166.

Miklosi, A., Topal, J. \& Csanyi, V. (2004) Comparative social cognition: what can dogs teach us? Anim Behav, 67, 995-1004.

Oberbauer, A.M., Berry, S.L., Belanger, J.M., McGoldrick, R.M., Pinos-Rodriquez, J.M. \& Famula, T.R. (2013) Determining the heritable component of dairy cattle foot lesions. Journal of dairy science, 96, 605-613.

Passalacqua, C., Marshall-Pescini, S., Barnard, S., Lakatos, G., Valsecchi, P. \& Previde, E.P. (2011) Human-directed gazing behaviour in puppies and adult dogs, Canis lupus familiaris. Anim Behav, 82, 1043-1050.

Perez-Guisado, J., Lopez-Rodriguez, R. \& Munoz-Serrano, A. (2006) Heritability of dominant-aggressive behaviour in English Cocker Spaniels. Appl Anim Behav Sci, 100, 219-227.

Pongracz, M., Miklosi, A., Vida, V. \& Csanyi, V. (2005) The pet dogs ability for learning from a human demonstrator in a detour task is independent from the breed and age. Appl Anim Behav Sci, 90, 309-323. 
Ruefenacht, S., Gebhardt-Henrich, S., Miyake, T. \& Gaillard, C. (2002) A behaviour test on German Shepherd dogs: heritability of seven different traits. Appl Anim Behav Sci, 79, 113-132.

Saetre, P., Strandberg, E., Sundgren, P.E., Pettersson, U., Jazin, E. \& Bergstrom, T.F. (2006) The genetic contribution to canine personality. Genes Brain Behav, 5, 240-248.

Schenkel, R. (1967) Submission: Its Features and Function in the Wolf and Dog. American Zoologist, 7, 319-329.

Serbezov, D., Bernatchez, L., Olsen, E.M. \& VØLlestad, L.A. (2010) Quantitative genetic parameters for wild stream-living brown trout: heritability and parental effects. J Evolution Biol, 23, 1631-1641.

Smith, B.P. \& Litchfield, C.A. (2013) Looking back at 'looking back': operationalising referential gaze for dingoes in an unsolvable task. Animal cognition, 16, 961-971.

Soproni, K., Miklosi, A., Topal, J. \& Csanyi, V. (2001) Comprehension of human communicative signs in pet dogs (Canis familiaris). Journal of comparative psychology, 115, 122-126.

Téglás, E., Gergely, A., Kupán, K., Miklósi, Á. \& Topál, J. (2012) Dogs' Gaze Following Is Tuned to Human Communicative Signals. Curr Biol, 22, 209212.

Topal, J., Miklosi, A. \& Csanyi, V. (1997) Dog-human relationship affects problem solving behavior in the dog. Anthrozoos, 10, 214-224.

Topal, J., Miklosi, A., Gacsi, M., Doka, A., Pongracz, P., Kubinyi, E., Viranyi, Z. \& Csanyi, V. (2009) The Dog as a Model for Understanding Human Social Behavior. Adv Stud Behav, 39, 71-116.

Udell, M.A.R., Ewald, M., Dorey, N.R. \& Wynne, C.D.L. (2014) Exploring breed differences in dogs (Canis familiaris): does exaggeration or inhibition of predatory response predict performance on human-guided tasks? Anim Behav, 89, 99-105.

van der Waaij, E.H., Wilsson, E. \& Strandberg, E. (2008) Genetic analysis of results of a Swedish behavior test on German Shepherd Dogs and Labrador Retrievers. Journal of animal science, 86, 2853-2861.

Vila, C., Savolainen, P., Maldonado, J.E., Amorim, I.R., Rice, J.E., Honeycutt, R.L., Crandall, K.A., Lundeberg, J. \& Wayne, R.K. (1997) Multiple and ancient origins of the domestic dog. Science, 276, 1687-1689.

Viranyi, Z., Gacsi, M., Kubinyi, E., Topal, J., Belenyi, B., Ujfalussy, D. \& Miklosi, A. (2008) Comprehension of human pointing gestures in young humanreared wolves (Canis lupus) and dogs (Canis familiaris). Animal cognition, 11, 373-387.

Visscher, P.M., Hill, W.G. \& Wray, N.R. (2008) Heritability in the genomics era concepts and misconceptions. Nat Rev Genet, 9, 255-266.

Wilson, A.J., Reale, D., Clements, M.N., Morrissey, M.M., Postma, E., Walling, C.A., Kruuk, L.E.B. \& Nussey, D.H. (2011) An ecologist's guide to the animal model (vol 79, pg 13, 2010). J Anim Ecol, 80, 1109-1109.

Wobber, V., Hare, B., Koler-Matznick, J., Wrangham, R. \& Tomasello, M. (2009) Breed differences in domestic dogs' (Canis familiaris) comprehension of human communicative signals. Interact Stud, 10, 206-224.

Yamasue, H., Yee, J.R., Hurlemann, R., Rilling, J.K., Chen, F.S., Meyer-Lindenberg, A. \& Tost, H. (2012) Integrative Approaches Utilizing Oxytocin to Enhance 
Prosocial Behavior: From Animal and Human Social Behavior to Autistic Social Dysfunction. J Neurosci, 32, 14109-+.

\section{Acknowledgements}

We are grateful to Astra Zeneca for allowing us to use the dogs, and in particular to the veterinarian Viveca Eriksson and the rest of the staff at the breeding unit for all help during the studies. The project was performed within the framework of Linköping University Neurobiology initiative (LiU Neuro), and the Swedish Center of Excellence in Animal Welfare Science, financed by Formas. The project was funded by the European Research Council (ERC) within the advanced grant “GENEWELL” (322206). 
Table 1: Feeding score. A score from 1-3 explaining the time it took for the dog to eat all treats presented on the single plate during the pre-test. Dogs that did not eat all 3 treats within 2 minutes were excluded from the study and did not perform the problem-solving test.

\begin{tabular}{ll}
\hline Score & Description \\
\hline 1 & Late feeding: it took between $40 \mathrm{sec}$ and 2 minutes until the dog ate \\
all the treats. For most of these dogs, one or more treats were eaten \\
off the floor.
\end{tabular}


Table 2: Ethogram of behaviours used in the analysis.

\begin{tabular}{|c|c|c|}
\hline $\begin{array}{l}\text { Behaviour } \\
\text { group }\end{array}$ & Behaviour & Definition \\
\hline \multirow[t]{3}{*}{ Position } & Test setup & The dogs' head is within its own body length of the test setup \\
\hline & Human & The dogs' head is within its own body length of the experimenter \\
\hline & Elsewhere & $\begin{array}{l}\text { The dogs' head is not within its own body length of either the test } \\
\text { setup or the experimenter }\end{array}$ \\
\hline \multirow{3}{*}{$\begin{array}{l}\text { Test setup } \\
\text { interactions }\end{array}$} & Solvable & Physical interactions with any of the two solvable tasks \\
\hline & Unsolvable & Physical interactions with the unsolvable task \\
\hline & $\begin{array}{l}\text { Solve } 1 \& \\
2\end{array}$ & $\begin{array}{l}\text { The duration until the dog solved the first and the second solvable } \\
\text { task }\end{array}$ \\
\hline \multirow[t]{2}{*}{$\begin{array}{l}\text { Human } \\
\text { interactions }\end{array}$} & $\begin{array}{l}\text { Eye } \\
\text { contact }\end{array}$ & $\begin{array}{l}\text { The dog is either positioned at the test setup, between the test setup } \\
\text { and the experimenter or at the experimenter while gazing towards the } \\
\text { face of the experimenter. }\end{array}$ \\
\hline & $\begin{array}{l}\text { Physical } \\
\text { contact }\end{array}$ & The dog is positioned at the experimenter and in physical contact. \\
\hline \multirow[t]{3}{*}{ Other } & $\begin{array}{l}\text { Feeding } \\
\text { Score }\end{array}$ & $\begin{array}{l}\text { A score from } 1 \text { to } 3 \text { (late to early feeding) explaining the time it took } \\
\text { for the dogs to eat the treats in the initial feeding test. See Table } 1 \text { for } \\
\text { details. }\end{array}$ \\
\hline & $\begin{array}{l}\text { Body } \\
\text { Posture } \\
\text { Score }\end{array}$ & $\begin{array}{l}\text { A score from } 1 \text { to } 5 \text { (high to low) of the overall body posture. Se Table } \\
3 \text { for details. }\end{array}$ \\
\hline & $\begin{array}{l}\text { Transition } \\
\text { Index }\end{array}$ & $\begin{array}{l}\text { The total number of transitions directly between the test setup and } \\
\text { the experimenter and vice versa. The dogs' head did not enter the } \\
\text { position zone "Elsewhere" between the transition from the zone of the } \\
\text { "Test setup" and "Human" but stayed within its own body length of } \\
\text { either "Test setup" or "Human". }\end{array}$ \\
\hline
\end{tabular}


Table 3: Body Posture Score. A subjective score from 1-5 explaining the body posture of the dog based upon overall body posture and behaviour shown towards the experimenter and the test setup.

\begin{tabular}{ll}
\hline Score & Description \\
\hline 1 & Confident: The dog acts confident throughout the test. Definition \\
of confident: Stands straight and tall with the head high and ears \\
held forward. The mouth may or may not be open but relaxed. The \\
tail may or may not wag while it is held high, neutral or hanging \\
down relaxed. Appears friendly and not threatened by the \\
surroundings. \\
Fairly confident: The dog acts confident most of the time but is \\
sometimes neutral or even slightly anxious (see the definition of \\
confident above and anxious below). \\
Neutral: The dog mostly acts neutral (neutral body posture, head \\
and tail position), however, it sometimes appear anxious. Definition \\
of anxious: May act submissive towards the test leader (low body \\
posture when approached, tail low and tense or even between the \\
hind legs, head lowered, neck stretched or the dog may even lay \\
down on its back). Ears are at least partially held back, the head is \\
lowered and the neck stretched. The dog stands tense and my \\
shudder. Tail is tensely held low or between the hind legs. \\
Approaches the test equipment cautiously (slowly with a lowered \\
body posture, tense body and tail and the tail is low or even \\
between the hind legs). \\
Often anxious: The dog sometimes acts neutral but is often \\
anxious and approaches the test equipment cautiously (see \\
definitions above). \\
Anxious: Appears anxious throughout the test and approaches the \\
test equipment cautiously (see definitions above).
\end{tabular}


Table 4: Principal component loadings of the different behavioural variable on each principal component.

\begin{tabular}{|c|c|c|c|c|}
\hline & Test interactions & Social interactions & Eye contact & Physical contact \\
\hline Freq. Solvable & 0.928 & -0.053 & 0.106 & -0.012 \\
\hline Dur. Solvable & 0.818 & -0.167 & 0.110 & 0.003 \\
\hline Dur. Test setup & 0.896 & -0.196 & 0.059 & 0.084 \\
\hline Freq. Test setup & 0.678 & 0.272 & 0.165 & -0.472 \\
\hline Lat. Test setup & -0.668 & -0.217 & -0.215 & 0.266 \\
\hline Freq. Unsolvable & 0.885 & -0.106 & 0.009 & 0.214 \\
\hline Dur. Unsolvable & 0.749 & -0.211 & -0.034 & 0.358 \\
\hline Lat. Solve 1 & -0.825 & 0.101 & -0.072 & -0.142 \\
\hline Lat. Solve 2 & -0.752 & 0.137 & -0.023 & -0.216 \\
\hline Feeding Score & 0.661 & 0.111 & 0.075 & 0.039 \\
\hline $\begin{array}{l}\text { Body Posture } \\
\text { Score }\end{array}$ & -0.661 & 0.002 & -0.013 & -0.111 \\
\hline Transition Index & 0.557 & 0.564 & 0.200 & -0.221 \\
\hline Dur. Human & -0.486 & 0.638 & 0.253 & 0.306 \\
\hline Lat. Human & -0.079 & -0.550 & -0.216 & 0.386 \\
\hline Freq. Human & -0.054 & 0.709 & 0.255 & -0.288 \\
\hline Freq. Physical & 0.023 & 0.837 & 0.169 & 0.351 \\
\hline Lat. Physical & -0.143 & -0.708 & -0.190 & -0.110 \\
\hline Dur. Physical & -0.231 & 0.637 & 0.245 & 0.536 \\
\hline Freq. Looking & 0.297 & 0.521 & -0.765 & -0.006 \\
\hline Dur. Looking & 0.234 & 0.512 & -0.719 & 0.021 \\
\hline Lat. Looking & -0.295 & -0.480 & 0.624 & 0.071 \\
\hline$\%$ of variance & 36.0 & 19.9 & 9.3 & 6.5 \\
\hline
\end{tabular}



Table 5: Heritability estimates of the PCA components.

\begin{tabular}{llll}
\hline & $\mathrm{h}^{2}$ & HPD low & HPD high \\
\hline Test interactions & 0.32 & 0.13 & 0.51 \\
Social interactions & 0.23 & 0.06 & 0.42 \\
Eye contact & 0.0008 & - & 0.21 \\
Physical contact & 0.0005 & - & 0.16 \\
\hline $95 \%$ HPD-intervals for both Eye contact and Physical contact have limits below \\
$10^{-8}$.
\end{tabular}


(a)

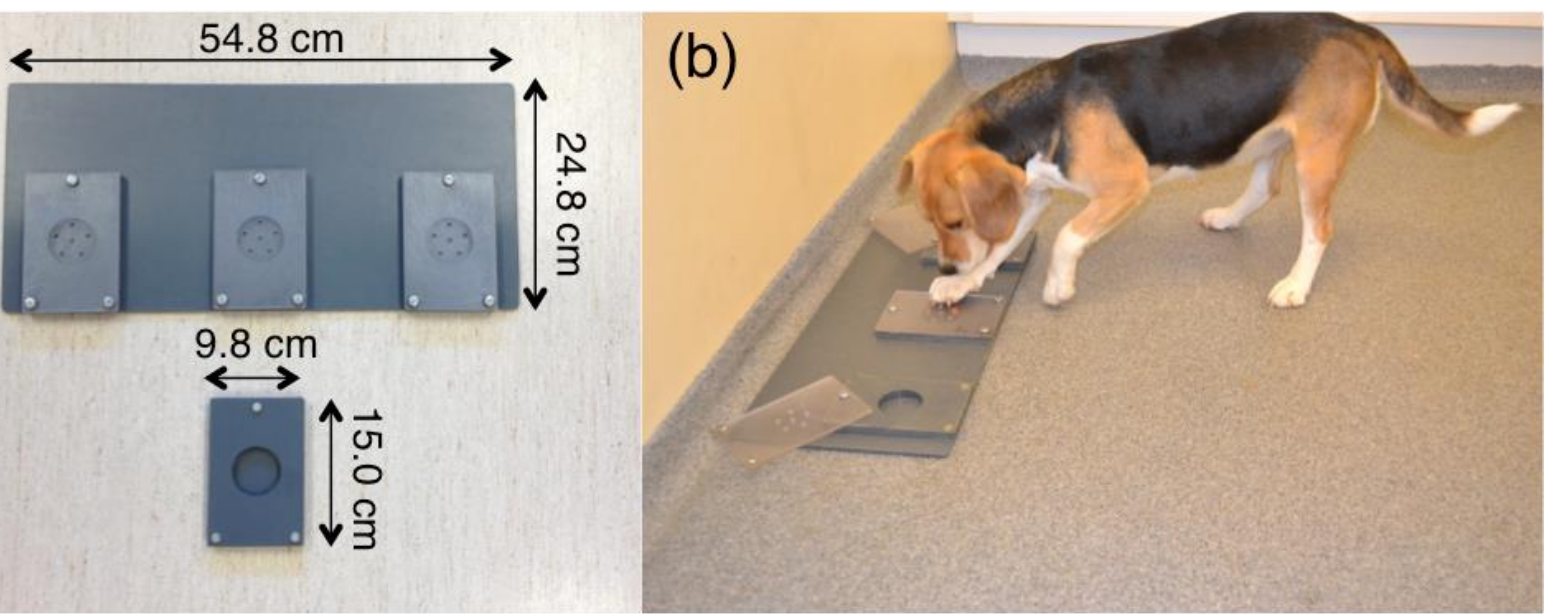



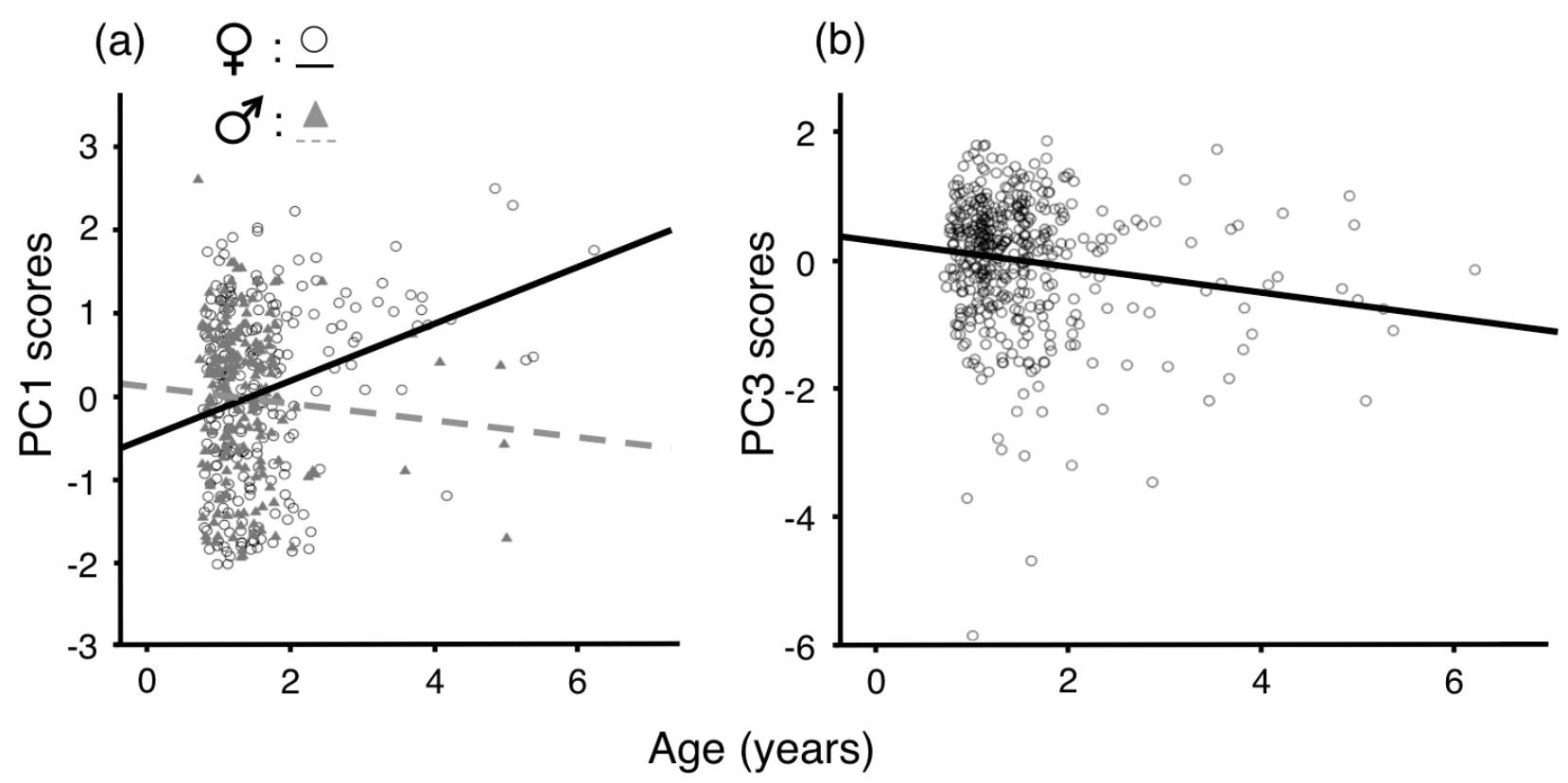


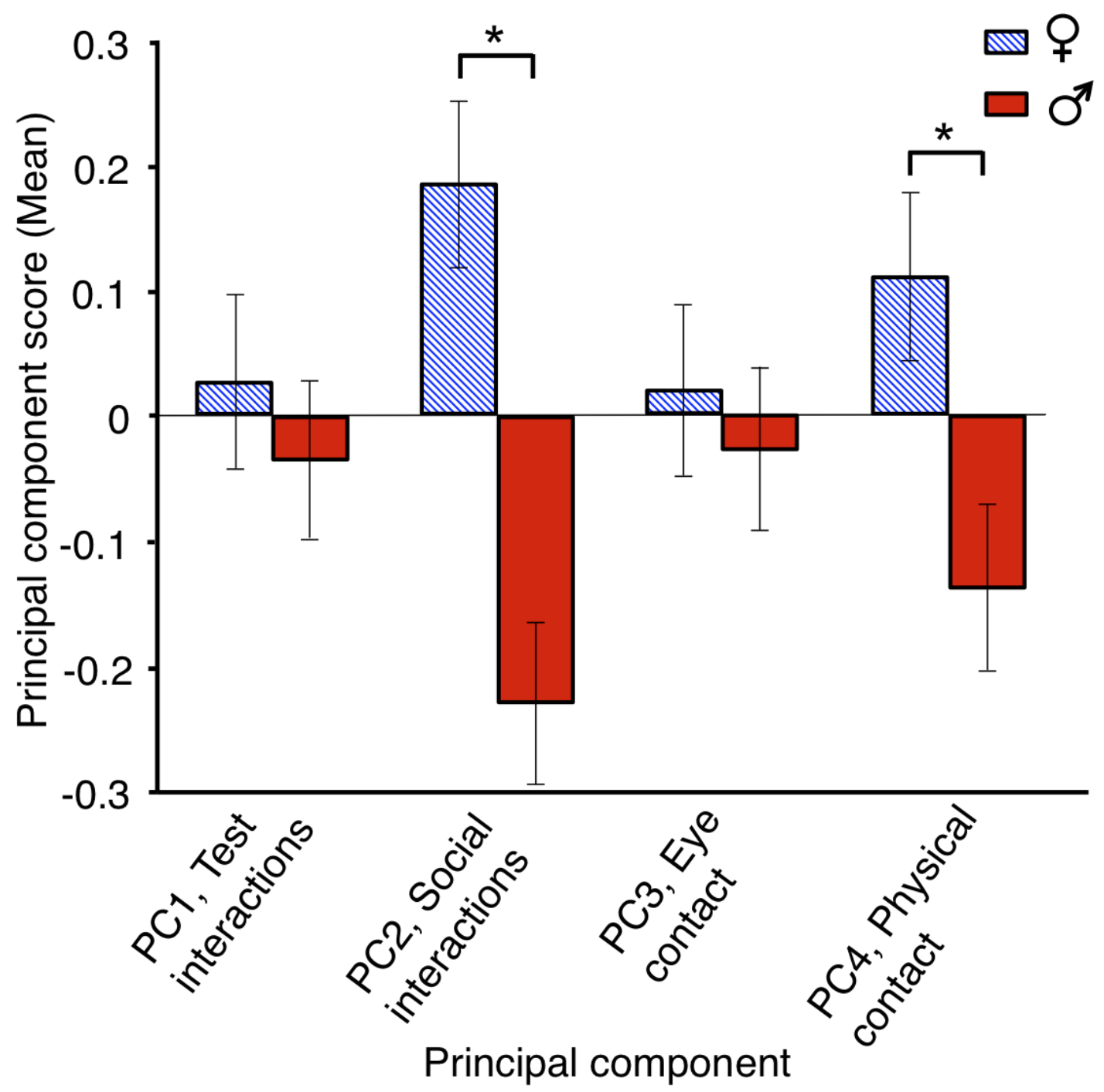




\section{Figure Legends}

Figure 1: The test apparatus. (a) The unsolvable task and single plate (below) used for the initial motivation test. The odour ports measure $0.5 \mathrm{~cm}$ in diameter. (b) one of the subjects attempting to open the unsolvable part of the equipment.

Figure 2: Effects of age (years) on the PCA component scores of PC1 and PC3.

(a) The effect of age on PC1 (test set interactions) component scores in females $\left(\mathrm{R}^{2}\right.$ $=0.076)$ and males $\left(R^{2}=0.005\right)$. (b) The effect of age on PC3 (eye contact) component scores $\left(R^{2}=0.018\right)$.

Figure 3: Effects of sex on the PCA component scores. Average PCA component scores ( \pm 1 SEM) for male and female dogs. 
Supplementary Table S1: Principal component analysis correlation matrix. The original correlation matrix to the principal component analysis. Sampling adequacy: Bartlett's sphericity test $\chi^{2}=7899.66$, df $=210, \mathrm{p}<0.001 ; \mathrm{KMO}: 0.855 . \mathrm{N}=437$.

\section{Correlation Matrix}

\begin{tabular}{|c|c|c|c|c|c|c|c|c|}
\hline & & $\begin{array}{l}\text { Transition } \\
\text { Index }\end{array}$ & $\begin{array}{l}\text { Feeding } \\
\text { Score }\end{array}$ & $\begin{array}{l}\text { Body } \\
\text { Posture } \\
\text { Score }\end{array}$ & $\begin{array}{c}\text { Duration } \\
\text { Testset }\end{array}$ & $\begin{array}{l}\text { Duration } \\
\text { Human }\end{array}$ & $\begin{array}{c}\text { Duration } \\
\text { Unsolvable }\end{array}$ & $\begin{array}{l}\text { Duration } \\
\text { Solvable }\end{array}$ \\
\hline \multirow[t]{30}{*}{ Correlation } & Transition Index & 1.000 & .379 & -.297 & .389 & .090 & .236 & .400 \\
\hline & Feeding Score & .379 & 1.000 & -.522 & .495 & -.272 & .410 & .460 \\
\hline & Body Posture & -.297 & -.522 & 1.000 & -.507 & .326 & -.430 & -.460 \\
\hline & Duration Testset & .389 & .495 & -.507 & 1.000 & -479 & 805 & .844 \\
\hline & Duration Human & .090 & -.272 & .326 & -.479 & 1.000 & -.360 & -.423 \\
\hline & Duration & & & & & & & \\
\hline & Unsolvable & .236 & .410 & -.430 & .805 & -.360 & 1.000 & .599 \\
\hline & Duration & 400 & 460 & -460 & 844 & -423 & 599 & 1000 \\
\hline & Solvable & .400 & .400 & -.400 & .844 & $-.4<0$ & (599. & 1.000 \\
\hline & Duration Looking & .290 & .157 & -.144 & .073 & .058 & .091 & .044 \\
\hline & Duration & 162 & -.069 & 115 & -260 & 749 & -197 & -215 \\
\hline & Physical & $.10<$ & -.009 & & & & -.191 & \\
\hline & Frequency & 680 & 429 & -380 & 510 & -25 & 220 & 485 \\
\hline & Testset & & & & & & & \\
\hline & Frequency & 508 & 018 & 088 & -191 & 488 & -188 & -161 \\
\hline & Human & & & & & & & \\
\hline & Frequency & 406 & 196 & -545 & 853 & -414 & 856 & 703 \\
\hline & Unsolvable & & & & & & & \\
\hline & Frequency & 513 & 535 & -570 & 866 & -446 & 648 & 839 \\
\hline & Solvable & 格. & . & - & .000 & .440 & . & \\
\hline & Frequency & 309 & 178 & -167 & 133 & 012 & 146 & 096 \\
\hline & Looking & . & .170 & -101 & .100 & .016 & .140 & .050 \\
\hline & Frequency & 131 & 141 & 073 & 118 & 582 & 075 & 114 \\
\hline & Physical & 1.4. & .141 & -.070 & -.110 & .302 & -.075 & -.114 \\
\hline & Latency Testset & -.477 & -.458 & .411 & -.543 & .189 & -.337 & -.494 \\
\hline & Latency Human & -.352 & -.105 & .018 & .027 & -.276 & .119 & -.017 \\
\hline & Latency Solve1 & -.372 & -.517 & .515 & -.709 & .403 & -.610 & -.645 \\
\hline & Latency Solve2 & -.266 & -.486 & .486 & -.617 & .377 & -.618 & -.543 \\
\hline & Latency Looking & -.287 & -.182 & .148 & -.131 & .007 & -.107 & -.100 \\
\hline & Latency Physical & -.403 & -.216 & .127 & .001 & -.326 & .019 & .013 \\
\hline \multirow{6}{*}{$\begin{array}{l}\text { Sig. (1- } \\
\text { tailed) }\end{array}$} & Transition Index & & .000 & .000 & .000 & .030 & .000 & .000 \\
\hline & Feeding Score & .000 & & .000 & .000 & .000 & .000 & .000 \\
\hline & Body Posture & (ח) & ח & & م00 & ח & م०० & 000 \\
\hline & Score & .000 & .000 & & .000 & .000 & .000 & .000 \\
\hline & Duration Testset & .000 & .000 & .000 & & .000 & .000 & .000 \\
\hline & Duration Human & .030 & .000 & .000 & .000 & & .000 & .000 \\
\hline
\end{tabular}




\begin{tabular}{l} 
Duration \\
Unsolvable \\
Duration \\
Solvable \\
Duration Looking \\
Duration \\
Physical \\
Frequency \\
Testset \\
Frequency \\
Human \\
Frequency \\
Unsolvable \\
Frequency \\
Solvable \\
Frequency \\
Looking \\
Frequency \\
Physical \\
Latency Testset \\
Latency Human \\
Latency Solve1 \\
Latency Solve2 \\
Latency Looking \\
Latency Physical \\
\hline
\end{tabular}

\begin{tabular}{|c|c|c|c|c|c|c|}
\hline .000 & .000 & .000 & .000 & .000 & & .000 \\
\hline . 000. & .000 & .000 & .000 & .000 & .000 & \\
\hline .000 & .000 & .001 & .064 & .111 & .029 & .181 \\
\hline .000 & .074 & .008 & .000 & .000 & .000 & .000 \\
\hline .000 & .000 & .000 & .000 & .000 & .000 & .000 \\
\hline .000 & .355 & .034 & .000 & .000 & .000 & .000 \\
\hline .000 & .000 & .000 & .000 & .000 & .000 & .000 \\
\hline .000 & .000 & .000 & .000 & .000 & .000 & .000 \\
\hline .000 & .000 & .000 & .003 & .403 & .001 & .022 \\
\hline .000 & .002 & .064 & .007 & .000 & .058 & .008 \\
\hline .000 & .000 & .000 & .000 & .000 & .000 & .000 \\
\hline .000 & .014 & .354 & .289 & .000 & .006 & .361 \\
\hline .000 & .000 & .000 & .000 & .000 & .000 & .000 \\
\hline .000 & .000 & .000 & .000 & .000 & .000 & .000 \\
\hline .000 & .000 & .001 & .003 & .444 & .012 & .018 \\
\hline .000 & .000 & .004 & .493 & .000 & .347 & .392 \\
\hline
\end{tabular}

\begin{tabular}{|c|c|c|c|c|c|c|c|c|}
\hline & & $\begin{array}{l}\text { Duration } \\
\text { Looking }\end{array}$ & $\begin{array}{l}\text { Duration } \\
\text { Physical }\end{array}$ & $\begin{array}{c}\text { Frequency } \\
\text { Testset }\end{array}$ & $\begin{array}{c}\text { Frequency } \\
\text { Human }\end{array}$ & $\begin{array}{l}\text { Frequency } \\
\text { Unsolvable }\end{array}$ & $\begin{array}{c}\text { Frequency } \\
\text { Solvable }\end{array}$ & $\begin{array}{c}\text { Frequency } \\
\text { Looking } \\
\end{array}$ \\
\hline \multirow[t]{10}{*}{ Correlation } & Transition Index & .290 & .162 & .680 & .508 & .406 & .513 & .309 \\
\hline & Feeding Score & .157 & -.069 & .429 & .018 & .496 & .535 & .178 \\
\hline & $\begin{array}{l}\text { Body Posture } \\
\text { Score }\end{array}$ & -.144 & .115 & -.380 & .088 & -.545 & -.570 & -.167 \\
\hline & Duration Testset & .073 & -.260 & .510 & -.191 & .853 & .866 & .133 \\
\hline & Duration Human & .058 & .749 & -.259 & .488 & -.414 & -.446 & .012 \\
\hline & $\begin{array}{l}\text { Duration } \\
\text { Unsolvable }\end{array}$ & .091 & -.197 & .229 & -.188 & .856 & .648 & .146 \\
\hline & $\begin{array}{l}\text { Duration } \\
\text { Solvable }\end{array}$ & .044 & -.215 & .485 & -.161 & .703 & .839 & .096 \\
\hline & Duration Looking & 1.000 & .106 & .168 & .183 & .139 & .117 & .892 \\
\hline & $\begin{array}{l}\text { Duration } \\
\text { Physical }\end{array}$ & .106 & 1.000 & -.121 & .281 & -.196 & -.193 & .078 \\
\hline & $\begin{array}{l}\text { Frequency } \\
\text { Testset }\end{array}$ & .168 & -.121 & 1.000 & .261 & .454 & .661 & .209 \\
\hline
\end{tabular}




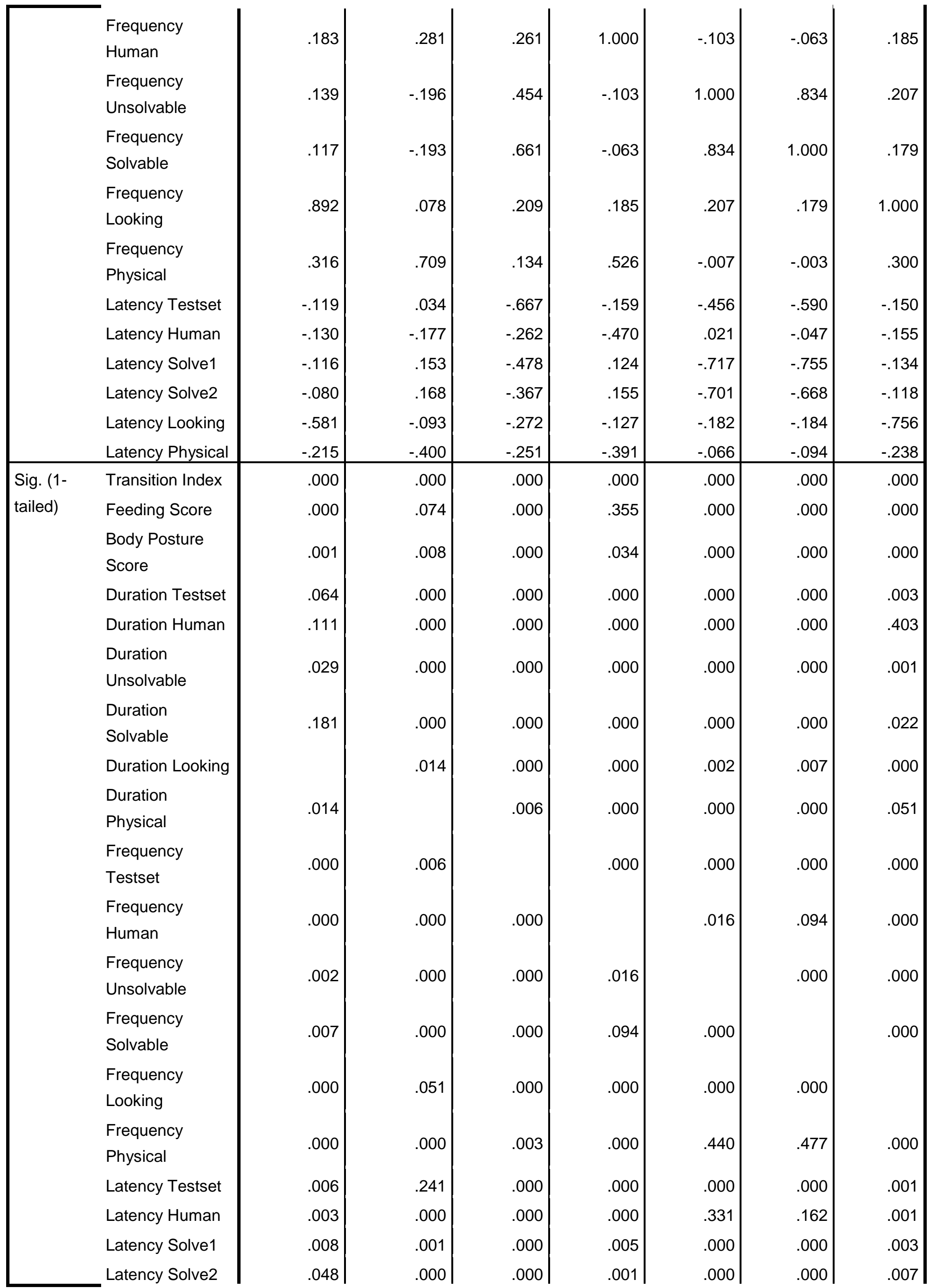




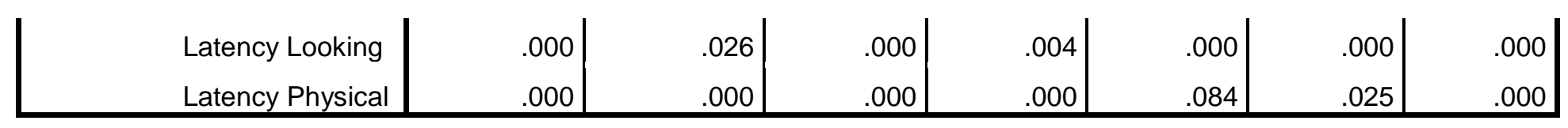

Correlation Matrix

\begin{tabular}{|c|c|c|c|c|c|c|c|c|}
\hline & & $\begin{array}{l}\text { Frequency } \\
\text { Physical }\end{array}$ & $\begin{array}{l}\text { Latency } \\
\text { Testset }\end{array}$ & $\begin{array}{l}\text { Latency } \\
\text { Human }\end{array}$ & $\begin{array}{c}\text { Latency } \\
\text { Solve1 }\end{array}$ & $\begin{array}{c}\text { Latency } \\
\text { Solve2 }\end{array}$ & $\begin{array}{l}\text { Latency } \\
\text { Looking }\end{array}$ & $\begin{array}{l}\text { Latency } \\
\text { Physical }\end{array}$ \\
\hline \multirow[t]{28}{*}{ Correlation } & Transition Index & .431 & -.477 & -.352 & -.372 & -.266 & -.287 & -.403 \\
\hline & Feeding Score & .141 & -.458 & -.105 & -.517 & -.486 & -.182 & -.216 \\
\hline & Body Posture & -073 & $\Delta 11$ & 018 & 515 & 486 & 148 & 127 \\
\hline & Score & .070 & ז & . & 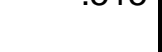 & .700 & .170 & . \\
\hline & Duration Testset & -.118 & -.543 & .027 & -.709 & -.617 & -.131 & .001 \\
\hline & Duration Human & .582 & .189 & -.276 & .403 & .377 & .007 & -.326 \\
\hline & Duration & -.075 & -.337 & .119 & -.610 & -.618 & -.107 & .019 \\
\hline & Duration Solvable & -.114 & -.494 & -.017 & -.645 & -.543 & -.100 & .013 \\
\hline & Duration Looking & .316 & -.119 & -.130 & -.116 & -.080 & -.581 & -.215 \\
\hline & Duration Physical & .709 & .034 & -.177 & .153 & .168 & -.093 & -.400 \\
\hline & Frequency & .134 & -.667 & -.262 & -.478 & -.367 & -.272 & -.251 \\
\hline & Testset & & & & & & & \\
\hline & Frequency & .526 & -.159 & -.470 & .124 & .155 & -.127 & -391 \\
\hline & Human & & & & & & & \\
\hline & Frequency & -007 & -456 & 021 & - 717 & - 701 & 180 & 066 \\
\hline & Unsolvable & -.007 & -.450 & .021 & -.717 & -.701 & -.182 & -.000 \\
\hline & Frequency & -003 & -590 & -047 & 755 & 668 & 184 & 094 \\
\hline & Solvable & -.003 & -.590 & -.047 & -.155 & -.608 & -.184 & -.094 \\
\hline & Frequency & 300 & 150 & 155 & 131 & 118 & 756 & ס20 \\
\hline & Looking & .300 & -.150 & -.155 & -.134 & -.118 & -.156 & -.238 \\
\hline & Frequency & 1000 & 141 & 286 & 006 & (2) & 250 & 681 \\
\hline & Physical & 1.000 & -.144 & -.286 & .006 & .042 & -.259 & -.684 \\
\hline & Latency Testset & -.144 & 1.000 & .244 & .517 & .385 & .217 & .238 \\
\hline & Latency Human & -.286 & .244 & 1.000 & -.031 & -.002 & .197 & .404 \\
\hline & Latency Solve1 & .006 & .517 & -.031 & 1.000 & .731 & 130 & .048 \\
\hline & Latency Solve2 & .042 & .385 & -.002 & .731 & 1.000 & .152 & .028 \\
\hline & Latency Looking & -.259 & .217 & .197 & .130 & .152 & 1.000 & .276 \\
\hline & Latency Physical & -.684 & .238 & .404 & .048 & .028 & .276 & 1.000 \\
\hline \multirow{10}{*}{$\begin{array}{l}\text { Sig. (1- } \\
\text { tailed) }\end{array}$} & Transition Index & .000 & .000 & .000 & .000 & .000 & .000 & .000 \\
\hline & Feeding Score & .002 & .000 & .014 & .000 & .000 & .000 & .000 \\
\hline & Body Posture & 064 & 000 & 354 & 000 & 000 & 001 & 004 \\
\hline & Score & & & & & & & \\
\hline & Duration Testset & .007 & .000 & .289 & .000 & .000 & .003 & .493 \\
\hline & Duration Human & .000 & .000 & .000 & .000 & .000 & .444 & .000 \\
\hline & Duration & .058 & .000 & .006 & .000 & .000 & .012 & .347 \\
\hline & Unsolvable & & & & & & & \\
\hline & Duration Solvable & .008 & .000 & .361 & .000 & .000 & .018 & .392 \\
\hline & Duration Looking & .000 & .006 & .003 & .008 & .048 & .000 & .000 \\
\hline
\end{tabular}




\begin{tabular}{|c|c|c|c|c|c|c|c|}
\hline Duration Physical & .000 & .241 & .000 & .001 & .000 & .026 & .000 \\
\hline $\begin{array}{l}\text { Frequency } \\
\text { Testset }\end{array}$ & .003 & .000 & .000 & .000 & .000 & .000 & .000 \\
\hline $\begin{array}{l}\text { Frequency } \\
\text { Human }\end{array}$ & .000 & .000 & .000 & .005 & .001 & .004 & .000 \\
\hline $\begin{array}{l}\text { Frequency } \\
\text { Unsolvable }\end{array}$ & .440 & .000 & .331 & .000 & .000 & .000 & .084 \\
\hline $\begin{array}{l}\text { Frequency } \\
\text { Solvable }\end{array}$ & .477 & .000 & .162 & .000 & .000 & .000 & .025 \\
\hline $\begin{array}{l}\text { Frequency } \\
\text { Looking }\end{array}$ & .000 & .001 & .001 & .003 & .007 & .000 & .000 \\
\hline $\begin{array}{l}\text { Frequency } \\
\text { Physical }\end{array}$ & & .001 & .000 & .448 & .192 & .000 & .000 \\
\hline Latency Testset & .001 & & .000 & .000 & .000 & .000 & .000 \\
\hline Latency Human & .000 & .000 & & .262 & .486 & .000 & .000 \\
\hline Latency Solve1 & .448 & .000 & .262 & & .000 & .003 & .161 \\
\hline Latency Solve2 & .192 & .000 & .486 & .000 & & .001 & .281 \\
\hline Latency Looking & .000 & .000 & .000 & .003 & .001 & & .000 \\
\hline Latency Physical & .000 & .000 & .000 & .161 & .281 & .000 & \\
\hline
\end{tabular}


Supplementary Table S2: Effects of sex, age and their interaction on the analysed behaviours. The second and third columns display the mean \pm SEM of male and female beagles followed by the $F$ and P-values. For the effects of age and the interaction between age and sex only $\mathrm{F}$ and $\mathrm{P}$-values are displayed.

\begin{tabular}{|c|c|c|c|c|c|c|c|c|}
\hline \multirow{2}{*}{ Behaviour } & \multicolumn{2}{|c|}{ Sex } & \multirow[b]{2}{*}{$\mathrm{F}$} & \multirow[b]{2}{*}{$\mathrm{P}$} & \multicolumn{2}{|c|}{ Age } & \multicolumn{2}{|c|}{ Age ${ }^{\star}$ Sex } \\
\hline & Males & Females & & & $\mathrm{F}$ & $\mathrm{P}$ & $\mathrm{F}$ & $\mathrm{P}$ \\
\hline Frequency Solvable & $12.70 \pm 0.55$ & $13.51 \pm 0.58$ & 5.799 & 0.016 & 0.069 & 0.793 & 9.379 & 0.002 \\
\hline Duration Solvable & $26.27 \pm 1.33$ & $28.18 \pm 1.40$ & 0.662 & 0.416 & 0.977 & 0.324 & - & - \\
\hline Duration Testset & $49.41 \pm 2.28$ & $52.24 \pm 2.38$ & 7.549 & 0.006 & 0.214 & 0.644 & 11.164 & 0.001 \\
\hline Frequency Testset & $5.11 \pm 0.18$ & $5.31 \pm 0.19$ & 0.211 & 0.646 & 3.436 & 0.064 & - & - \\
\hline Latency Testset & $20.31 \pm 3.28$ & $25.47 \pm 3.41$ & 1.562 & 0.212 & 1.428 & 0.233 & - & - \\
\hline Frequency Unsolvable & $6.75 \pm 0.38$ & $7.47 \pm 0.44$ & 11.667 & 0.001 & 4.011 & 0.046 & 17.012 & 0.000 \\
\hline Duration Unsolvable & $12.18 \pm 1.00$ & $13.78 \pm 1.06$ & 12.503 & 0.000 & 4.039 & 0.045 & 17.536 & 0.000 \\
\hline Latency Solve 1 & $94.01 \pm 4.49$ & $99.01 \pm 4.08$ & 9.640 & 0.002 & 0.329 & 0.567 & 8.464 & 0.004 \\
\hline Latency Solve 2 & $127.17 \pm 4.06$ & $125.61 \pm 3.68$ & 4.638 & 0.032 & 3.072 & 0.080 & 5.378 & 0.021 \\
\hline Feeding Score & $2.06 \pm 0.06$ & $2.16 \pm 0.06$ & 0.561 & 0.454 & 9.062 & 0.003 & - & - \\
\hline Body Posture & $2.46 \pm 0.08$ & $2.69 \pm 0.08$ & 6.237 & 0.013 & 11.421 & 0.001 & - & - \\
\hline Transition Index & $3.00 \pm 0.16$ & $3.70 \pm 0.18$ & 1.141 & 0.286 & 1.615 & 0.204 & 5.874 & 0.016 \\
\hline Duration Human & $29.18 \pm 2.01$ & $38.80 \pm 2.27$ & 11.029 & 0.001 & 2.456 & 0.118 & - & - \\
\hline Latency Human & $22.89 \pm 2.68$ & $19.32 \pm 2.17$ & 0.991 & 0.320 & 0.055 & 0.815 & - & - \\
\hline Frequency Human & $4.86 \pm 0.20$ & $5.67 \pm 0.19$ & 8.713 & 0.003 & 0.149 & 0.700 & - & - \\
\hline Frequency Physical & $1.72 \pm 0.13$ & $2.86 \pm 0.15$ & 29.176 & 0.000 & 0.001 & 0.981 & - & - \\
\hline Latency Physical & $85.29 \pm 5.61$ & $58.10 \pm 4.39$ & 13.605 & 0.000 & 0.714 & 0.399 & - & - \\
\hline Duration Physical & $9.51 \pm 1.19$ & $16.74 \pm 1.51$ & 15.075 & 0.000 & 3.324 & 0.069 & - & - \\
\hline Frequency Looking & $0.49 \pm 0.07$ & $0.71 \pm 0.09$ & 1.854 & 0.174 & 6.763 & 0.010 & 4.933 & 0.027 \\
\hline Duration Looking & $0.60 \pm 0.11$ & $0.90 \pm 0.15$ & 1.275 & 0.260 & 7.027 & 0.008 & - & - \\
\hline Latency Looking & $141.17 \pm 4.86$ & $125.14 \pm 4.83$ & 3.282 & 0.071 & 9.983 & 0.002 & - & - \\
\hline
\end{tabular}

For the analysis, Univariate General Linear Models in SPSS Statistics 22 was used with sex as a fixed factor and age (years) as a covariate. If the interaction was not significant it was removed from the model and only the main effects of sex and age was included. 